重症骨盤骨折から心タンポナーデを来した 1 症例

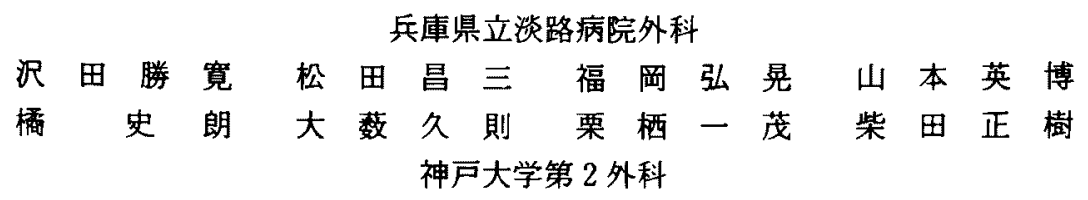

服部哲也春名宏樹築 部卓 郎

重应骨盤骨折から心タンボナーデを来した症例を経験したので報告する，症例は31歳 の女性. 自殺企図にてビルの3陛り飛び降りて倒れているのを発見された。来院時の 血圧は触診で50mmHgのンョック状態であった。レ線検査で骨盤骨折と両下駺骨折が判 明し，他の外倁は否定されたので骨盤骨折による出血性ショックと診断した. 第 2 病日， 多量の输血にてる血行動態が安定せず，血腹か疑われたので試験開腹術を行ったところ， 高度の後腹膜腔出血と渗み出したと思われる少量の腹腔内出血を認めたのみであった。 第 5 病日.CVPの上昇と頻脈が出現し, 胸部レ線と心エコーで血胸・心タンボナーデと 診断した，胸腔ドレナーシ，心震切開ドレナージを行ったところ，多量の血珄胸水と血 性心覆夜の排出を認め，以後血行動態は安定していった。このように骨盤骨折は単に後 腹膜出血にとどまらず，様々な病態を呈してくるので骨折の治療のみならず，呼吸・循 環管理を含めた喛重な全身管理と，迅速かつ適切な治療が必要であると思われた。

索引用語：骨盤骨折, 血胸, 心タンポナーデ

はじめに

骨盤骨折はその部位の特殊性から後腹膜出血を伴う ことが多く、それによる出血性ショック，多缄器不全， DIC 等で不幸な転機をとることもけっして稀ではな い。わわれは骨盤骨折から血性腹水・血性胸水・心 タンボナーデを来したが救命し得た 1 症例を経験し た。われわれが調べ得たかぎりでは，骨盤骨折による 後腹膜出血から、心タンポナーデを来した報告はみら れず，極めて稀な症例と考光られるので若干の文嘀的 考察を加えて報告する。

\section{症例}

患者：31藏女性.

主訴：意識障害, ショック。

既往歴：5つ病，疾病妄想で精神科受診中であった。

現病歴：昭和62年 4 月29日午前 4 時頃，急に家を飛 び出して行き，家人が搜していたところ，国道沿いの ビルの下で倒れているのを発見され，救急車で運びこ まれた。したがって，来院時は受傷の状況は不明で，
後になってビルの 3 階から飛び降りたことが判明し た。

来院時現症：血圧 $50 \mathrm{mmHg}$ (触診)，脈拍 $120 / \mathrm{min}$, 意識, 傾眠傾向. 顔面, 前額部, 口唇に挫創を認めた。 胸部には特に異常認めず，腹部には外傷，腹满，筋性 防御は諗めず。両側下根に皮下出血, 骨折による異常 可動性及びクリック音を認めた。

来院時検査所見：白血球 $15,200 / \mathrm{mm}^{3}$, 赤血球 $209 \times$ $10^{4} / \mathrm{mm}^{3}$, 血小板 $19.1 \times 10^{4} / \mathrm{mm}^{3}$, Hct $20.1 \%$, Hb 6.8 $\mathrm{g} / \mathrm{dl}$, 血清アミラーゼ206U, GOT 50U, GPT 52U, LDH $622 \mathrm{U}$ ，尿潜血：(一)，胸部レ線，腹部レ線：異 常なし，ECG：NSR，ST-T波に異常なし。

入院経過（図 1 ）：先ず静脈確保を行い輸血を開始し つつ検査を進めていった，頭部 CT 検査では異常なく 胸部，腹部レ線でも特に異常は認めなかった。骨盤お よび下肢のレ線検查で，骨盤の左右の坐骨および恥骨 の多発骨折と，左仙腸関節脱臼のいわゆる骨盤環複合 骨折を認め(図 2)，両側怪骨にも骨折を認めた。この 時点の腹部エュー検查では腹空内出血は認めなかっ た. 以上の所見より骨盤骨折による出血性ショックと 


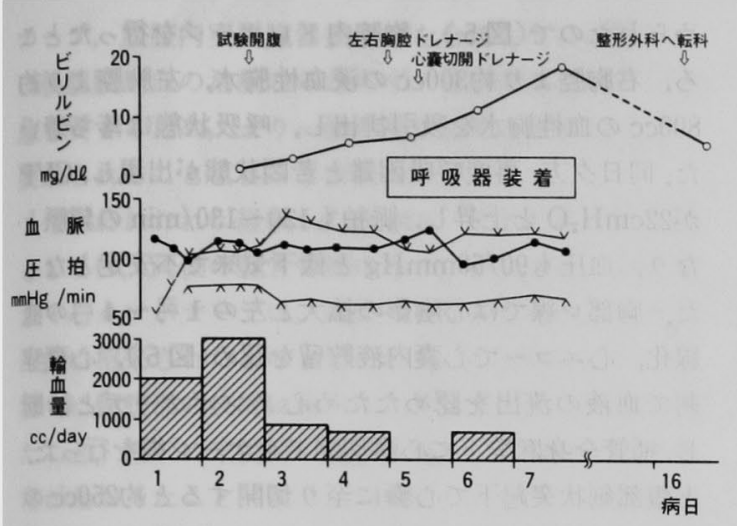

図 1 臨床経過

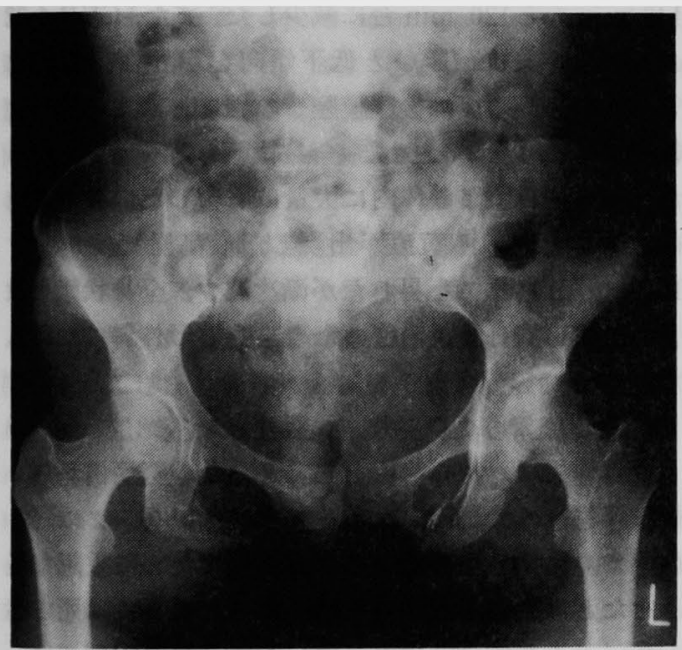

図2 骨盤環複合骨折：左右の坐骨および恥骨の多発 骨折と左仙腸関節脱臼を認める.

診断しさらに輸血を続けた。約 6 時間で $2,000 \mathrm{ml}$ の輸 血を行ったところ, 血圧は $100 / 60 \mathrm{mmHg}$ ，脈拍は $100 /$ $\min , \mathrm{CVP}$ は $6.8 \mathrm{cmH}_{2} \mathrm{O}$ と落ち着いてきたが, 腹部膨 隆が出現し殿部，会陰部にも著明な腫張が出現してき た.このときの腹部レ線では, free air はないもののガ ス像は著明で麻疩性イレゥスの状態であった。その後 る渝血をつつけていたか，輸血速度を遅くすると血王 か70〜80 mm Hg に低下する状態で, 腹部 CT で後腹 膜腔への出血とともに腹腔内液体眝留も認められたの で(図 3)，腹部外傷による腹腔内出血の可能性も否定 できず，第 2 病日午後 8 時 30 分試験開腹術を行った。 開腹したところ腹腔内には約 $400 \mathrm{cc}$ の血性腹水を認め たものの, 脾臓, 肝臓, 腸間膜などに損傷は無く、そ
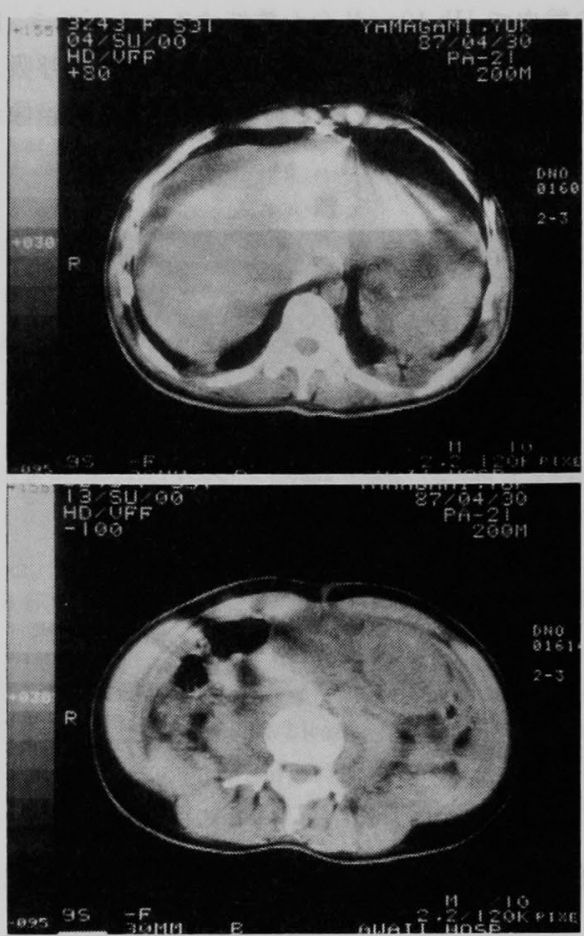

図 3 腹部 CT：後腹膜腔への出血と腹腔内出血が見 られる.

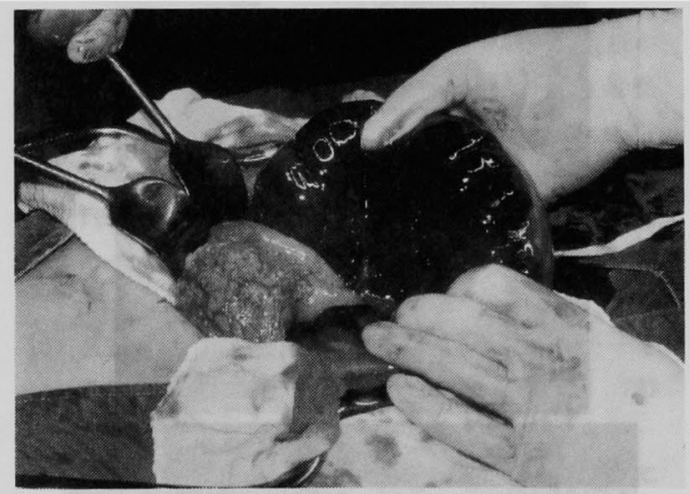

図4術中写真(開腹時)：後腹膜出血が腸間膜にもお よび肥厚している.

の他の管腔藏器にも異常は無かった。しかしながら， 後腹膜腔には多量の出血を認め, 後腹膜が腹側に挙上 され，腸間膜内にも出血が及んで肥厚していた(図4). したがって, 腹腔内出血は後腹膜腔の出血がみ出し てきたものと判断された。 その後は未だ軽度の後腹膜 出血が続いているとは思われたか，1 日600cc〜1,000 
$\mathrm{cc}$ の輸血で $\mathrm{Hb} 10 \mathrm{~g} / \mathrm{dl}$ 台を維持することができ，血行 動態も比較的安定していた，第 5 病日朝，過呼吸と呼 吸困難が出現し胸部レ線で両側の胸腔内液詝留像が認

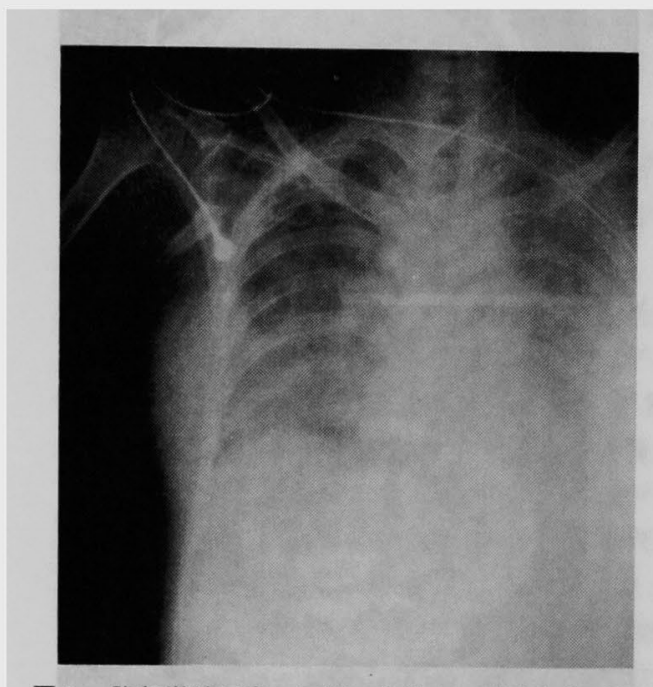

図 5 胸部単純写真：両側の胸腔内に液貯留像が認め られる。

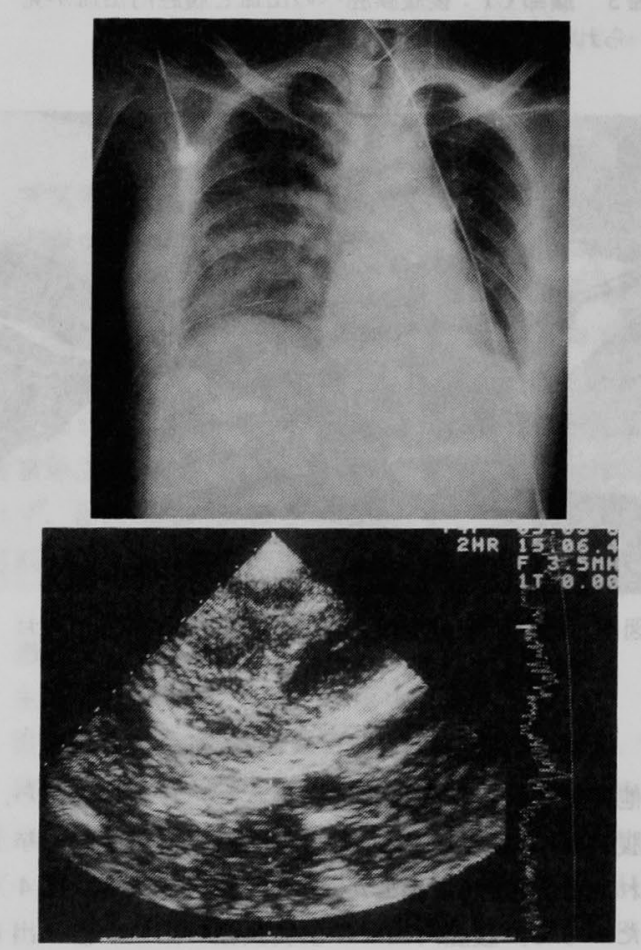

図 6 胸部単純写真と心エコー：心陰影の拡大と左の 1 弓〜 4 弓の直線化，心囊内液貯留を認める.
められたので(図 5)，胸腔内ドレナージを行ったとこ ろ, 右胸腔より約 $300 \mathrm{cc}$ の淡血性胸水, 左胸腔より約 $800 \mathrm{cc}$ の血性胸水を吸引排出し，呼吸状態は落ち着い た. 同日夕方, 再度呼吸困難之苦悶状態かi出現し, CVP が $22 \mathrm{cmH}_{2} \mathrm{O}$ と上昇し, 脈拍も $120 \sim 130 / \mathrm{min}$ の頻脈之 なり, 血王も $90 / 60 \mathrm{mmHg}$ と低下気味で不安定となっ た. 胸部レ線では心陰影の払大と左の 1 弓〜 4 弓の直 線化，心ェコーで心变内液貯留を認め(図 6)，心要穿 刺で血液の流出を認めたため心タンポナーデと診断 し, 㨉管全身麻酔下に心衰切開ドレナージ術を行った。 上腹部剣状突起下で心要に至り切開すると約 $250 \mathrm{cc} の$ 暗赤色の血性心襄液が流出した。この処置にて血王が $100 \mathrm{mmHg}$ から $120 \mathrm{mmHg}$ に上昇し，反対に脈拍数は 140/min から $120 / \mathrm{min}$ 台に减少した。 また, CVP る22 $\mathrm{cmH}_{2} \mathrm{O}$ か5 $20 \mathrm{cmH}_{2} \mathrm{O}$ と低下傾向を示し血行動態は 安定した，その後は後腹膜腔への出血も治まっていき 輸血もあまり必要とせず，全身状態も落ち着いていっ た. 第 6 病日頃より体内に大量に貯留した血液の溶血 によると思われる黄疸が出現し, 最高総ピリルピン $14.6 \mathrm{mg} / \mathrm{dl}$ にまで上昇したが漸次減少, 全身状態も改 善し，第14病日骨折治療のため当院整形外科に転科し た.

考察

骨盤骨折は，特に治療を必要としない軽症例から， 後腹膜腔への大量出血によって出血性ショックに宿る 症例や，胸部・腹部などの合併損伤のために重篤な経 過をたどる症例などすありそのような場合には死亡率 も高い。こに合併損傷を伴った多発外傷症例では, 真栄城らが述べているように，治療は一診療科にとど まらす゚多くの診療科に亘り複雑で困難であり，治療方 針に関する的確な判断と，迅速な処置が要求される1! 死亡原因としてもっとも多いのは出血性ショックであ $\eta^{233)}$ 骨盤骨折単独でも3,000cc 以上の輸血を必要とす ることが多く4，また受傷後 8 時間で $2,000 \mathrm{cc}$ 以上の輸 血を要する症例は重症であるとの報告もある5．最近 このような骨盤骨折に伴ら後腹膜出血に対して, Transcatheter Arterial Embolization (TAE) の有効 性が認められるとの報告も散見され，この症例のよら に大量の後腹膜出血を来すさいには考慮すべき治療法 と思われた 6)7)8)99.

多発外傷として骨盤骨折をとらえてみると合併損偤 部位としては一般的に, 頭部, 胸部, 腹部, 四肢が多 いとされ(0)，全身に加わった鈍的外傷の特徵とも言え る.とりわけ重症骨盤骨折で, 緊張性気胸, 心タンボ 


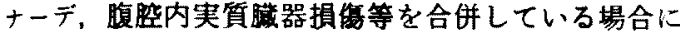
は偻腹獏出血の治療のみならず，合併損偒の治療が婜 急を要するため，上り一層的確な診断と丑速な治療が 要求されることは言らまですない11121.

今回われわれが経験した症例は，受診時の合併損傷 としては，両側の怪骨骨折のみで，血性腹水・血性胸 本・心タンポナーデは，大量の後腹膜出血によって二 如的招来されたすのと思われた。 その理由としては， 第一に胸腹部の皮席に明らかな外傷が認められなかっ たこと，第二に来院時の胸部レ線および腹部レ線で異 常がなかったこと，第三に来院時の心電図で心筋挫傷 を示す ST，T波の異常がなかったこと、第四に来院時 の腹部エコー検查で腹腔内出血を認めなかったことな とである。そして第 2 病日に試输開腹を行ったところ，

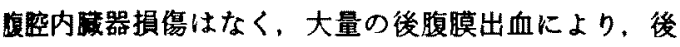
腹膜腔より又出た出血が腹腔内にみられたわけで， 同しょらな機序で出血が胸腔および心竡に搪がったも のと考えられた。

骨盤骨折に胸腹部外傷を合併し，血腹，血胸や心タ ンボナーデを来すことは十分あり得ることで，前述の 上5に文献的にも散見される。心タンボナーデの発生 機序としては，外㑥性の心損偒や大血管破裂考之ら れるか，先に述べたよらに，来院時の心電图所見で特 に心挫鹪を示唆する所見が無いことや，大血管の損傷 にしては症状の発現が緩徐であった事などを考光合わ せると，やはり骨盤骨折による大量の後腹膜曌への出 血が心タンボナーデの原因と思われるのである.

われわれの調べ得たかぎりでは，本症例のように， 明らかに胸腹部外偒の合併が否定されるのに，血胸・ 心タンボナーデを来したような症例の報告はみられ ナ゙,きわめて稀な症例と思われた。このように胸腹部 外第を伴わなくてる，血胸や心タンボナーデを来すよ らな骨盤骨折症例するので，重症骨盤骨折患者を管 理していく5えては，常に呼吸·循環動態をる把握し， 起こり得る合併症に対して迅速かつ的確に診断し，治 噔を行っていくことが重要であると考えられた。

$$
\text { まとめ }
$$

骨舴骨折による後腹膜出血から，心タンボナーデを 米たし教命し得た症例を報告した。本症例のように，
胸腹部外鹪が無くても血胸や心タンポナーデを来す場 合があるので，重症の骨盤骨折症例では，呼吸・循環 管理を含めた褯重な全身管理と，迅速かつ適切な治㞠 が重要であると思われた。

\section{文 献}

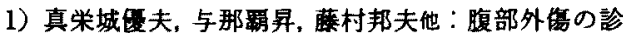
断之治療，外科治療 $31: 74-85 ， 1974$

2) John GG, John FP Jr: Retro-peritoneal hematoma following trauma: Its clinical importance. J Trauma $20: 733-736,1980$

3) Jeffrey JB, Frederick LG, Rodney DM : Vascular injuries associated with pelvic fractures. Am Surgeon $50: 150-154,1984$

4) 政田和洋, 山沢 猛,桂田菊嗣他：骨盤骨折の種類 之副損稘，整－災外 $24: 1035-1040 ， 1981$

5) Flint LM, Brown A, Richardson JD, et al : Definitive control of bleeding from severe pelvic fracture. Ann Surg 189: 709-716, 1979

6) Mark GG, Richard EW, Timothy CF, et al: Peritoneal lavage and angiography in the management of patients with pelvic fractures. Am J Surg $144: 744-747,1982$

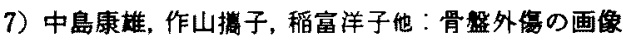
診断一CT の有用性について一，救急医 8:625 $-631,1984$

8）加来信雄，北里諴也，内野良彦他：重应骨盤骨折の 大量出血に対する内腸骨動脈塞拴術，救急医 $11: 1743-1752,1987$

9) Panetta T, Sclafani SJA, Goldstein AS, et al : Percutaneous transcatheter embolization for massive bleeding from pelvic fractures. J Trauma $25: 1021-1029.1985$

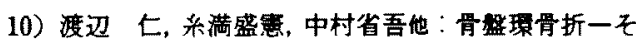
の生命予後に閔与する因子一, 整・級外 $28: 737$ $-741,1985$

11）伊江朝次，本竹秀光，上原哲夫他：重庭骨盤骨折比

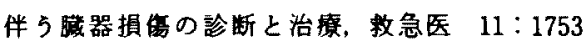
$-1759,1987$

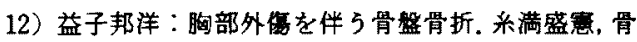
盤骨折と合併損傷, 南正堂, 東京, 1987, p139-145 


\title{
A CASE OF SEVERE PELVIC FRACTURE WITH CARDIAC TAMPONADE
}

\author{
Katsuhiro SAWADA, Shouzou MATSUDA, Hiroaki FUKUOKA, Hidehiro YAMAMOTO, \\ Shirou TACHIBANA, Hisanori OOYABU, Shigeru KURISU, Masaki SHIBATA, \\ Tetsuya HATTORI*, Hiroki HARUNA* and Takurou TSUKUBE* \\ Department of Surgery, Hyogo Prefectural Awaji Hospital \\ *Second Department of Surgery, Kobe University School of Medicine
}

The present paper reports a case of severe pelvic fracture resulting in hemoperitoneum, hemothorax and cardiac tamponade. A 31-year-old woman was found unconcious after plunging from the third floor of a building in an attempted suicide. She was in shock and her blood pressure was $50 \mathrm{mmHg}$ by palpation on arrival. Since roentgenography revealed pelvic fracture and bilateral leg fracture, and no other traumas were noted, she was diagnosed as having hemorrhagic shock due to pelvic fracture. On the 2nd day exploratory laparotomy was performed for suspected hemoperitoneum because her hemodynamic state was not stabilized by massive blood transfusion. Severe retroperitoneal hemorrhage and small amount of blood in the abdominal cavity, which was presumably exuded from the retroperitoneum, were found. On the 5th day the patient presented elevated CVP and tachycardia. Diagnosis of hemothorax and cardiac tamponade was made by chest roentgenography and echocardiography. Her hemodynamic condition became stable after a massive amount of bloody pleural fluid and bloody pericardial effusion was discharged by drainage of the thoracic cavity and drainage with pericardiotomy. As shown in the present case, patients with pelvic fracture tend to develop not only retroperitoneal hemorrhage but various pathological conditions. Therefore, careful management of their general condition, including respiration and circuration, as well as prompt and appropriate care, are required in addition to treatment of fracture. 